\title{
Intrinsic Motivation, Knowledge Sharing and Innovation Behavior of Knowledge-Based Employees in the Industrial New Generation
}

\author{
Xiaohua Yu ${ }^{1}$, Xiulan Meng ${ }^{2 *}$ \\ ${ }^{\text {I}}$ Zhejiang Guangsha Vocational and Technical University of Construction, Zhejiang Jinhua 322100, \\ China \\ ${ }^{2}$ Xingzhi college Zhejiang Normal University, Zhejiang Jinhua 321004, China \\ *Corresponding Author.
}

\begin{abstract}
By introducing knowledge sharing as an intermediary variable and using 375 questionnaires, this paper makes an empirical study on the intrinsic motivation, the main and mediating effects of knowledge sharing on individual innovation behavior. The results show that: (1) The intrinsic motivation has a positive predictive effect on individual innovation behavior, and the influence degree of each dimension on individual innovation behavior is beta interest > beta competency > beta curiosity > beta self-determination > beta work engagement. (2) The intrinsic motivation has a positive predictive effect on knowledge sharing. Besides self-determination, all dimensions of intrinsic motivation can actively promote knowledge sharing among employees, such as competency, work engagement, curiosity and interest. (3) Knowledge sharing has a partial mediating effect on the relationship between internal motivation and individual innovation behavior of knowledge-based employees in the industrial new generation. Knowledge sharing plays a mediating role in the influence of competency, work engagement, curiosity and interest on individual innovation behavior, but does not have a mediating effect on self-determination. The conclusions of this study can provide reference and suggestions for enterprises to effectively promote individual innovation of the industrial new generation of employees.
\end{abstract}

Keywords: Intrinsic motivation; knowledge sharing; individual innovation behavior; knowledge-based employees in the industrial new generation

\section{Question Raising}

The complex and transient new market environment further underscores the importance of knowledge-based employees. Enterprises need not only a large number of knowledge-based employees, but also their tremendous development potential, especially in the era of innovation. Under the background of innovation-driven development strategy, as the main power source of innovation, knowledge-based employees are valued by enterprises. Alibaba, ByteDance and Lenovo, the well-known domestic enterprises, are competing for talents in order to get the multiplier effect of the innovation behavior of knowledge-based employees. Moreover, the Talent Identification Program of Huawei is a great affirmation of the innovation behavior of knowledge-based employees. However, how to stimulate the innovation behavior of knowledge-based employees is a matter of great concern to business managers and academic circles, which gradually introduces the research perspective to the individual level.

Foreign scholars Gagne M. et al. ${ }^{[1]}$ believed that intrinsic motivation, as a variable of psychological needs, has a significant impact on employee performance, work engagement and so on. Employees' intrinsic psychological needs are the fundamental motivation to stimulate their innovation potential. For example, employees with high-level intrinsic motivation devote more time and energy to their work than ordinary employees, and constantly try and challenge themselves with better perseverance and persistence ${ }^{[2]}$, which will inevitably affect their innovation behavior and output. A review of the literature reveals that there is little research on the impact

ISSN: 0010-8189

(C) CONVERTER 2020 
mechanism between intrinsic motivation and individual innovation behavior in the current academic community, and there is still room for exploration.

Second, in the era of knowledge economy, knowledge sharing has become the focus of research, and scholars have studied its impact on individual behavior from the organizational level and the individual level. For example, the effects of knowledge sharing on organizational performance, organizational innovation ability and team creativity are studied at the organizational level ${ }^{[3-5]}$. The impacts of knowledge sharing on post-variables such as individual performance, individual creativity of employees and individual innovation are analyzed at the individual level ${ }^{[6-7]}$. The main factors affecting knowledge sharing are enterprise craftsman spirit, leadership behavior, time pressure, etc. ${ }^{[5][8-9]}$. Thus, although there are relatively rich research results on the individual level of knowledge sharing, most of them are concentrated in the post variables, and the pre variables are mostly set in others. There is still possibility for further exploration from the individual micro perspective. Therefore, knowledge sharing behavior will therefore continue to be studied at the individual level in the hope of getting updated research results.

Based on the above analysis, starting from the knowledge carrier, the industrial new generation of knowledge-based employees are studied by introducing intrinsic motivation, knowledge sharing and innovation behavior as research variables, to explore the intrinsic mechanism of action among the three by using self-determination theory, motivation theory, etc., which is helpful to enrich the research results of knowledge sharing.

\section{Theoretical Analysis and Hypotheses}

\subsection{Intrinsic motivation to individual innovation behavior}

Psychologist Woodworth $(1918)^{[10]}$ believed that intrinsic motivation is the individual's self-motivated curiosity that drives his or her perception and action. According to self-determination theory, the more motivated people are, the stronger their desire for work and achievement and their willingness to learn and explore. Passion, curiosity and challenge motivate employees to proactively find more problem solutions, resulting in a high level of creativity ${ }^{[1]}$. Research has proved that the industrial new generation of knowledge-based employees with high intrinsic motivation level have a relatively large work investment and dedication to innovation, which can significantly and positively affect individual innovation performance and work performance ${ }^{[12]}$. The creativity component model has also shown that the intrinsic motivation can urge individuals to complete tasks based on their curiosity and interest to produce creative results, becoming an important pre-factor for individual creativity ${ }^{[13]}$. Thus, the following hypothesis is made:

H1: Intrinsic motivation promotes individual innovation behavior.

\subsection{Intrinsic motivation to knowledge sharing}

There are two main perspectives on the definition of knowledge sharing. One is that knowledge sharing is an inter-organizational behavior of exchanging information, viewpoints, opinions and specialties among organizations to help others, and the other is a process of exchanging tacit or explicit knowledge and creating new knowledge among team members from an individual perspective. In 2021, Yang Hong and other scholars defined knowledge sharing as a complex process involving the collection, absorption, learning and application of knowledge by the team and its members ${ }^{[8]}$. In this paper, knowledge sharing behavior research at individual level mainly refers to the process of exchanging and learning knowledge, skills and information among organization members.

Self-determination theory holds that intrinsic motivation can promote individuals to keep a high degree of curiosity, be more willing to work, study and explore, and actively discover new ways and methods through communication and study to satisfy their own interests and curiosity, thus generating knowledge sharing behavior. Employees with higher levels of intrinsic motivation are more likely to have a strong desire for work and a stronger willingness to

ISSN: 0010-8189 
learn and explore. They show enthusiasm, curiosity and challenge for work through their cognition and behavior, which makes them more inclined to find various solutions to problems, and will actively seek cooperation and communicate with each other in order to obtain more solutions ${ }^{[11]}$. Thus, the following hypothesis is made:

H2: Intrinsic motivation enhances knowledge sharing behavior.

\subsection{Knowledge sharing to individual innovation behavior}

In an organization, the knowledge capital set of all employees is a huge knowledge network, in which each individual is densely distributed, and the connection between these nodes can promote the flow of knowledge resources. However, individual employees have different knowledge capitals and ways of thinking, and these heterogeneous cognitive resources will help stimulate innovative thinking. Therefore, knowledge exchange and interaction among individuals is crucial to their individual innovation behavior.

Since the existing knowledge reserve of the industrial new generation of knowledge-based employees cannot meet the knowledge requirements of self-goal realization and the advancement of the organization with the times, knowledge sharing has become an important channel for individuals to obtain external knowledge. In this way, individuals constantly exchange and integrate, acquire the innovative knowledge of other subjects in the organization, and absorb it into their own knowledge after their own understanding and processing, so as to solve problems creatively ${ }^{[14]}$. Individual innovation is a new way, a new method, a new idea, etc., which itself needs to continuously absorb new knowledge for timely self-renewal, so as to lay the foundation for innovation. Thus, the following hypothesis is made:

H3: Knowledge sharing promotes individual innovation behavior.

\subsection{The mediating role of knowledge sharing}

Knowledge is the cornerstone of innovation, and knowledge sharing can improve employees' innovation behavior. In the process of sharing and communication with others, employees can learn new knowledge, integrate their original knowledge to promote individual innovation ${ }^{[15]}$, and effectively reduce the limitations of their knowledge through the digestion and absorption of knowledge sharing, giving more possibilities for creative behavior. Whether or not to share knowledge is closely related to employees' own factors. For example, Employees with desire for achievement and strong curiosity are more willing to share knowledge actively, and those with higher pursuit of work are also more willing to exchange information. Vander et al. (2005) ${ }^{[16]}$ further verified that intrinsic motivation has an impact on knowledge sharing.

Thus, the following hypothesis is made:

H4: Knowledge sharing plays an mediating role between intrinsic motivation and individual innovation behavior

The theoretical model studied in this paper is shown in Fig. 1:

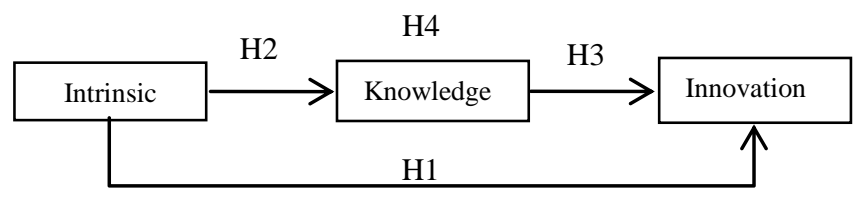

Fig. 1 Research framework

\section{Scale Design and Sample Description}

3.1 Measuring tools

ISSN: 0010-8189

(C) CONVERTER 2020

www.converter-magazine.info 
Based on the research scale of scholars Amabile et al. (1994) ${ }^{[13]}$ and Li Wei et al. (2013) ${ }^{[12]}$, 14 measurement items were constructed for intrinsic motivation from five dimensions: self-determination, competency, work engagement, curiosity and interest, with the Cronbach $\alpha$ value of 0.916 and all measurement items acceptable. Based on the scale of Vandenhooff et al. (2003) ${ }^{[17]}, 9$ measurement items were constructed for knowledge sharing from two dimensions: knowledge contribution and knowledge absorption, with the Cronbach $\alpha$ value of 0.936 and all measurement items acceptable. Based on the univariate structure scale developed by Yang Jingzhao et al. (2012) ${ }^{[18]}, 6$ measurement items were constructed for innovation behavior with the Cronbach $\alpha$ value of 0.933 and all measurement items acceptable. In this paper, employees' gender, age, marital status, education level, and years of employment in this enterprise were selected as control variables to examine their influence on individual innovation.

\subsection{Research samples}

In this paper, some urban enterprises in Zhejiang Province, Jiangsu Province and Henan Province were selected for the survey, and the survey subjects mainly focused on employees born after 1980. To control survey respondents to meet the characteristics of the knowledge-based employees of the industrial new generation studied in this paper, the educational level of individuals was set as a required item, and only the entry in the column of employees with college education level or above is valid. Among the enterprises investigated in this paper, private enterprises account for $49.1 \%$, foreign-funded enterprises account for $33.0 \%$, and the rest are state-owned holding enterprises. A total of 500 questionnaires were distributed and 447 questionnaires were returned, of which 375 were valid, with an effective rate of $75 \%$. Among them, $56 \%$ were male, $44 \%$ were female, $28.3 \%$ were married, and $71.7 \%$ were unmarried. $86.7 \%$ of the employees have worked for less than 3 years and 3-5 years, $48.8 \%$ of them are college students, $43 \%$ are undergraduate students, and a relatively small number have master's degree or above.

\section{Empirical Test and Result Interpretation}

In this paper, AMOS21.0 was used to analyze the data by confirmatory factor analysis to study the differential validity of each variable, and SPSS24.0 was used to test the reliability and validity of the data, descriptive statistical analysis, correlation analysis and regression analysis.

\subsection{Confirmatory factor analysis}

1. Analysis of validity of intrinsic motivation. In the intrinsic motivation scale, the KMO value of 14 items was 0.872, the chi-square value of Bartlett test was 2072.873, and the sig value was 0.000 , indicating that the scale data could be factor analyzed. Factor load analysis showed that x1, x 2 and x 3 loads were on one factor, which was named as "self-determination" according to the content of measurement items. In the same way, the factors formed by $x 4$ and x 5 were named "Competency", by x6, x7, x8 and x9 were named "Work engagement", by x10, x11 and x12 were named "Curiosity", and by x13 and x14 were named "Interest". The factor load of all items was greater than 0.6, which indicated that the intrinsic motivation scale had good structural validity. To simplify the research formula, the five factors were renamed as $\mathrm{X} 1, \mathrm{X} 2, \mathrm{X} 3, \mathrm{X} 4$ and $\mathrm{X} 5$, and the intrinsic motivation $\mathrm{F} 1=0.609 \mathrm{X} 1+0.14 \mathrm{X} 2+0.105 \mathrm{X} 3+0.083 \mathrm{X} 4+0.063 \mathrm{X} 5$ was obtained by using the variance contribution rate of each factor as the weight.

2. Analysis of validity of knowledge sharing. In the knowledge sharing scale, the KMO value of 9 items was 0.835 , the chi-square value of Bartlett test was 1995.986, and the sig value was 0.000, indicating that the scale data could be factor analyzed. Factor load analysis was performed on the nine items. The factors formed by $\mathrm{m} 1, \mathrm{~m} 2, \mathrm{~m} 3, \mathrm{~m} 4$, and $\mathrm{m} 5$ were named as "Knowledge contribution", by m6, m7, m8, and m9 were named as "Knowledge absorption". The two factors were named as M1 and M2. Finally, the knowledge sharing score $\mathrm{F} 2=0.860 \mathrm{M} 1+0.140 \mathrm{M} 2$ was calculated. 
3. Analysis of validity of individual innovation behavior. In the individual innovation behavior scale, the KMO value of 6 items was 0.900, the chi-square value of Bartlett test was 768.749, and the sig value was 0.000 , indicating that the scale data could be factor analyzed. Univariate analysis was performed on individual innovation behavior. The new data automatically generated by the system was named as Y1, and the value was the score of individual innovation behavior, i.e., $\mathrm{F} 3=\mathrm{Y} 1$.

\subsection{Correlation analysis}

Table 1 shows that the correlation coefficients of intrinsic motivation, knowledge sharing and innovation behavior are positive numbers, all are significant. It is thus preliminarily judged that there is a positive correlation among the three. Moreover, all dimensions of intrinsic motivation are positively correlated with the correlation coefficient of knowledge sharing and innovation behavior, and are significant. The maximum data of the above correlation coefficient was 0.477 , which was less than the square root of AVE value. It is thus believed that the discriminant validity of the research scale was also good, and further regression test can be carried out.

Table 1 Correlation analysis among research variables

\begin{tabular}{|c|c|c|c|c|c|c|c|c|}
\hline Variables & $\begin{array}{c}\text { Intrinsic } \\
\text { motivati } \\
\text { on }\end{array}$ & $\begin{array}{c}\text { Self-det } \\
\text { erminat } \\
\text { ion }\end{array}$ & $\begin{array}{c}\text { Compete } \\
\text { ncy }\end{array}$ & $\begin{array}{c}\text { Work } \\
\text { engagem } \\
\text { ent }\end{array}$ & $\begin{array}{l}\text { Curios } \\
\text { ity }\end{array}$ & $\begin{array}{l}\text { Inter } \\
\text { est }\end{array}$ & $\begin{array}{c}\text { Knowle } \\
\text { dge } \\
\text { sharing }\end{array}$ & $\begin{array}{c}\text { Innovati } \\
\text { on } \\
\text { behavior }\end{array}$ \\
\hline $\begin{array}{l}\text { Intrinsic } \\
\text { motivation }\end{array}$ & 1 & & & & & & & \\
\hline $\begin{array}{l}\text { Self-determina } \\
\text { tion }\end{array}$ & $.227^{* *}$ & 1 & & & & & & \\
\hline Competency & $.346^{* *}$ & $.313^{* *}$ & 1 & & & & & \\
\hline $\begin{array}{c}\text { Work } \\
\text { engagement }\end{array}$ & $.281^{* *}$ & $.477^{* *}$ & $.295^{* *}$ & 1 & & & & \\
\hline Curiosity & $.371^{* *}$ & $.275^{* *}$ & $.213^{*}$ & $.287^{* *}$ & 1 & & & \\
\hline Interest & $.417^{* * *}$ & $.242^{* *}$ & $.484^{* *}$ & $.325^{* *}$ & $.315^{* *}$ & 1 & & \\
\hline $\begin{array}{c}\text { Knowledge } \\
\text { sharing }\end{array}$ & $.393^{* *}$ & $.180^{* *}$ & $.378^{* *}$ & $.304^{* *}$ & $.380^{* *}$ & $.356^{*}$ & 1 & \\
\hline $\begin{array}{c}\text { Innovation } \\
\text { behavior }\end{array}$ & $.474^{* *}$ & $.309^{* *}$ & $.298^{* *}$ & $.361^{* *}$ & $.287^{* *}$ & $.509^{*}$ & $.339^{* *}$ & 1 \\
\hline
\end{tabular}

Note: $* * *$ means $\mathrm{p}<0.001, * *$ means $\mathrm{p}<0.01$ and $*$ means $\mathrm{p}<0.05$

\subsection{Hypothesis testing}

In order to verify the hypotheses in this paper, multiple linear regression analysis was used, and the results are as follows:

4.3.1.Regression analysis of intrinsic motivation to individual innovation behavior

In Model 1, seven variables such as gender, marriage and age are taken as control variables, and individual innovation behavior is taken as a dependent variable. Then the internal motivation is included in the regression model. The maximum variance inflation factor (VIF) for the control variable was 2.396, which excluded multicollinearity for the explanatory variable. In model $1, \mathrm{R}^{2}$ is 0.141 , and $\mathrm{F}$ is 3.680 , which is significant at $\mathrm{p}<$ 0.01 level, indicating that there are some control variables that have an impact on individual innovation behavior. From the analysis results, the educational level has a significant impact on individual innovation behavior $(\beta=0.133$, $\mathrm{p}=0.017$ ), which indicates that the educational background of the industrial new generation of knowledge-based employees affects individual innovation. In model 2, intrinsic motivation is added as an explanatory variable, and the $\mathrm{R}^{2}$ value of the model is 0.662 , which is significant at the level of $\mathrm{p}<0.001$, and intrinsic motivation is significantly positively correlated with individual innovation behavior $(\beta=0.810, \mathrm{p}=0.000)$, thus $\mathrm{H} 1$ is verified (as shown in Table 2).

ISSN: 0010-8189 
Table 2 Regression analysis of intrinsic motivation of knowledge-based employees of the industrial new generation on individual innovation behavior

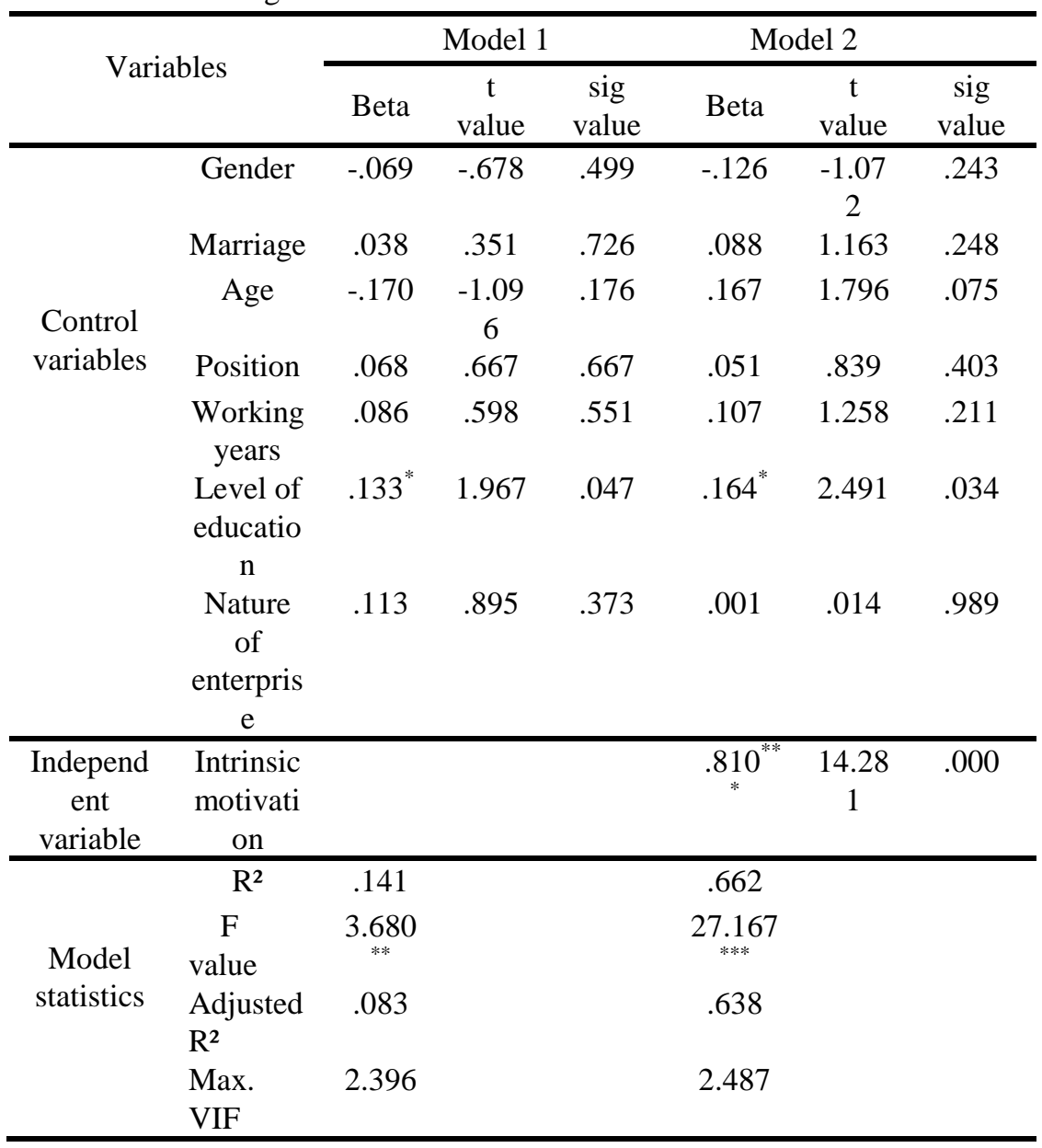

Further hierarchical regression analysis is made on the relationship between each dimension of intrinsic motivation and individual innovation behavior (shown in Table 3). The standard regression coefficients of self-determination and individual innovation behavior are significant $(\beta=0.094, p=0.33)$, competency and individual innovation behavior are significant $(\beta=0.279, \mathrm{p}=0.008)$, and work engagement, curiosity and interest are all positive and significant. Table 3 shows that the standard regression coefficient of interest and individual innovation behavior is the largest $(\beta=0.318, p=0.000)$, indicating that interest has the greatest effect on individual innovation behavior. The order of influence degree of each dimension is $\beta$ interest $>\beta$ competency $\beta$ curiosity $>\beta$ self-determination $>\beta$ work engagement.

Table 3 Regression analysis of each dimension of intrinsic motivation of knowledge-based employees of the industrial new generation on individual innovation behavior

\begin{tabular}{ccccccccc}
\hline & & \multicolumn{3}{c}{ Model 1 } & & \multicolumn{2}{c}{ Model 2 } \\
\cline { 3 - 8 } & Variables & & Beta & $\begin{array}{l}\mathrm{t} \\
\text { value }\end{array}$ & $\begin{array}{l}\text { sig } \\
\text { value }\end{array}$ & Beta & $\begin{array}{l}\mathrm{t} \\
\text { valu } \\
\mathrm{e}\end{array}$ & $\begin{array}{l}\text { sig } \\
\text { value }\end{array}$ \\
\cline { 3 - 8 } & & & & & & & \\
& Gender & -.069 & -.678 & .499 & -.123 & -1.7 & .088 \\
Control & Marriage & .038 & .351 & .726 & .020 & 1.24 & .218 \\
variables & & & & & & 1 & \\
& Age & -.170 & -1.09 & .176 & .093 & .978 & .330
\end{tabular}

ISSN: 0010-8189 


\begin{tabular}{|c|c|c|c|c|c|c|c|}
\hline \multicolumn{8}{|c|}{6} \\
\hline & Position & .068 & .667 & -.667 & .034 & .543 & .588 \\
\hline & $\begin{array}{c}\text { Working } \\
\text { vears }\end{array}$ & .086 & .598 & .551 & .069 & .804 & .423 \\
\hline & $\begin{array}{l}\text { Level of } \\
\text { education }\end{array}$ & $.133^{*}$ & 1.967 & .047 & $.136^{*}$ & $\begin{array}{c}2.02 \\
1\end{array}$ & .042 \\
\hline & $\begin{array}{c}\text { Nature of } \\
\text { enterpris } \\
\mathrm{e}\end{array}$ & .113 & .895 & .373 & .021 & .354 & .724 \\
\hline \multirow{11}{*}{$\begin{array}{c}\text { Independ } \\
\text { ent } \\
\text { variables }\end{array}$} & Self-dete & & & & $.094^{*}$ & 2.08 & .033 \\
\hline & rmination & & & & & 0 & \\
\hline & Compete & & & & .279 & 3.80 & .000 \\
\hline & ncy & & & & & 6 & \\
\hline & Work & & & & $.085^{*}$ & 2.02 & .042 \\
\hline & engagem & & & & & 4 & \\
\hline & ent & & & & & & \\
\hline & Curiosity & & & & $.212^{*}$ & 2.31 & .026 \\
\hline & & & & & & 6 & \\
\hline & Interest & & & & $.318^{* * *}$ & 4.17 & .000 \\
\hline & & & & & & 7 & \\
\hline \multirow{4}{*}{$\begin{array}{c}\text { Model } \\
\text { statistics }\end{array}$} & $\mathrm{R}^{2}$ & .141 & & & .687 & & \\
\hline & F value & 3.680 & & & 19.614 & & \\
\hline & $\begin{array}{c}\text { Adjusted } \\
\mathrm{R}^{2}\end{array}$ & .083 & & & .652 & & \\
\hline & $\begin{array}{c}\text { Max. } \\
\text { VIF }\end{array}$ & 2.396 & & & 2.495 & & \\
\hline
\end{tabular}

Note: $* * *$ means $\mathrm{p}<0.001, * *$ means $\mathrm{p}<0.01$ and $*$ means $\mathrm{p}<0.05$.

4.3.2 Regression analysis of intrinsic motivation to knowledge sharing

As shown in Table 4, the explanatory variables in Model 1 only include seven control variables, knowledge sharing is a dependent variable, and VIF value is far less than 10, thus eliminating multicollinearity among explanatory variables. The $\mathrm{F}$ value is 1.542 , significant at $\mathrm{p}<0.05$ level, indicating that there are variables that influence knowledge sharing among the control variables, and the regression coefficients of working years and education level are 0.276 and 0.319 respectively, which are both significant at $\mathrm{p}<0.05$ level, indicating that working years and level of education have a positive impact on knowledge sharing. Intrinsic motivation is added as an independent variable in model 2 , and there is no multicollinearity among explanatory variables. The results show that the regression coefficient of intrinsic motivation and knowledge sharing is positive and significant $(\beta=0.709, p=0.000)$, which indicates that high-level intrinsic motivation can actively promote employees' knowledge sharing behavior apart from the effects of the control variables, thus $\mathrm{H} 2$ is verified.

Table 4 Regression analysis of intrinsic motivation of knowledge-based employees of the industrial new generation on knowledge sharing

\begin{tabular}{cccccccc}
\hline & & \multicolumn{3}{c}{ Model 1 } & \multicolumn{3}{c}{ Model 2 } \\
\cline { 3 - 8 } & Variables & & $\mathrm{t}$ & sig \\
& Beta & $\begin{array}{c}\mathrm{t} \\
\text { value }\end{array}$ & value & Beta & $\begin{array}{c}\text { valu } \\
\mathrm{e}\end{array}$ & $\begin{array}{c}\text { sig } \\
\text { value }\end{array}$ \\
\hline \multirow{4}{*}{ Control } & Gender & .087 & .881 & .380 & .038 & .543 & .589 \\
& Marriage & .052 & .488 & .626 & .058 & .773 & .441 \\
& Age & -.195 & -1.60 & .121 & .392 & .520 & .610 \\
& & & 7 & & & & \\
\hline
\end{tabular}

ISSN: 0010-8189 


\begin{tabular}{|c|c|c|c|c|c|c|c|}
\hline \multirow[t]{4}{*}{$\begin{array}{c}\text { variable } \\
\text { s }\end{array}$} & Position & -.069 & -.690 & .491 & -.054 & $\begin{array}{c}-.77 \\
8\end{array}$ & .438 \\
\hline & $\begin{array}{c}\text { Working } \\
\text { years }\end{array}$ & $.216^{*}$ & 1.979 & .050 & $.295^{* *}$ & $\begin{array}{c}3.04 \\
4\end{array}$ & .003 \\
\hline & $\begin{array}{l}\text { Level of } \\
\text { education }\end{array}$ & $.257^{* *}$ & 2.587 & .005 & $.297^{* *}$ & $\begin{array}{c}3.46 \\
2\end{array}$ & .001 \\
\hline & $\begin{array}{c}\text { Nature of } \\
\text { enterpris } \\
\mathrm{e}\end{array}$ & .071 & .755 & .452 & -.045 & $\begin{array}{c}-.68 \\
1\end{array}$ & .498 \\
\hline $\begin{array}{c}\text { Indepen } \\
\text { dent } \\
\text { variable }\end{array}$ & $\begin{array}{c}\text { Intrinsic } \\
\text { motivatio } \\
n\end{array}$ & & & & $.709^{* * * *}$ & $\begin{array}{c}10.9 \\
99\end{array}$ & .000 \\
\hline \multirow{4}{*}{$\begin{array}{c}\text { Model } \\
\text { statistics }\end{array}$} & $\mathrm{R}^{2}$ & .188 & & & .564 & & \\
\hline & F value & $\underset{* *}{4.542}$ & & & ${ }_{* * *} 7.918^{*}$ & & \\
\hline & $\begin{array}{c}\text { Adjusted } \\
\mathrm{R}^{2}\end{array}$ & .156 & & & .532 & & \\
\hline & $\begin{array}{c}\text { Max. } \\
\text { VIF }\end{array}$ & 2.143 & & & 2.246 & & \\
\hline
\end{tabular}

Note: $* * *$ means $\mathrm{p}<0.001, * *$ means $\mathrm{p}<0.01$ and $*$ means $\mathrm{p}<0.05$.

The influence of each dimension of intrinsic motivation on knowledge sharing is shown in Table 5 that the standard regression coefficient of self-determination and knowledge sharing is not significant. In addition, the standard regression coefficients of competency, work engagement, curiosity, interest and knowledge sharing are $0.241,0.109,0.398$ and 0.131 , which are all significant, so that the total interpretation rate of results is improved.

Table 5 Regression analysis of knowledge sharing in different dimensions of intrinsic motivation of knowledge-based employees of the industrial new generation

\begin{tabular}{|c|c|c|c|c|c|c|c|}
\hline & \multirow[b]{2}{*}{ Variables } & \multicolumn{3}{|c|}{ Model 1} & \multicolumn{2}{|c|}{ Model 2} & \multirow[b]{2}{*}{$\begin{array}{c}\text { sig } \\
\text { value }\end{array}$} \\
\hline & & Beta & $\begin{array}{c}\mathrm{t} \\
\text { value }\end{array}$ & $\begin{array}{c}\text { sig } \\
\text { value }\end{array}$ & Beta & $\begin{array}{c}\mathrm{t} \\
\text { valu } \\
\mathrm{e}\end{array}$ & \\
\hline \multirow{7}{*}{$\begin{array}{c}\text { Control } \\
\text { variables }\end{array}$} & Gender & -.087 & -.881 & .380 & .033 & .472 & .638 \\
\hline & Marriage & .052 & .488 & .626 & .073 & .940 & .350 \\
\hline & Age & -.195 & $\begin{array}{c}-1.60 \\
7\end{array}$ & .121 & -.042 & $\begin{array}{c}-1.1 \\
53\end{array}$ & .252 \\
\hline & Position & .069 & .690 & .491 & .038 & .529 & .598 \\
\hline & $\begin{array}{c}\text { Working } \\
\text { years }\end{array}$ & $.216^{*}$ & 1.979 & .050 & $.267^{* *}$ & $\begin{array}{c}2.71 \\
3\end{array}$ & .008 \\
\hline & $\begin{array}{c}\text { Level of } \\
\text { educatio } \\
n\end{array}$ & $.257^{*}$ & 2.587 & .005 & $.231^{*}$ & $\begin{array}{c}2.45 \\
9\end{array}$ & .016 \\
\hline & $\begin{array}{c}\text { Nature of } \\
\text { enterpris } \\
\mathrm{e}\end{array}$ & .071 & .755 & .452 & .066 & .974 & .332 \\
\hline \multirow{3}{*}{$\begin{array}{c}\text { Independ } \\
\text { ent } \\
\text { variable }\end{array}$} & $\begin{array}{l}\text { Self-dete } \\
\text { rminatio }\end{array}$ & & & & -.032 & $\begin{array}{c}-.32 \\
0\end{array}$ & .750 \\
\hline & $\begin{array}{c}\mathrm{n} \\
\text { Compete } \\
\text { ncy }\end{array}$ & & & & $.241^{*}$ & $\begin{array}{c}2.16 \\
4\end{array}$ & .029 \\
\hline & Work & & & & $.109^{*}$ & 1.97 & .046 \\
\hline
\end{tabular}

ISSN: 0010-8189 


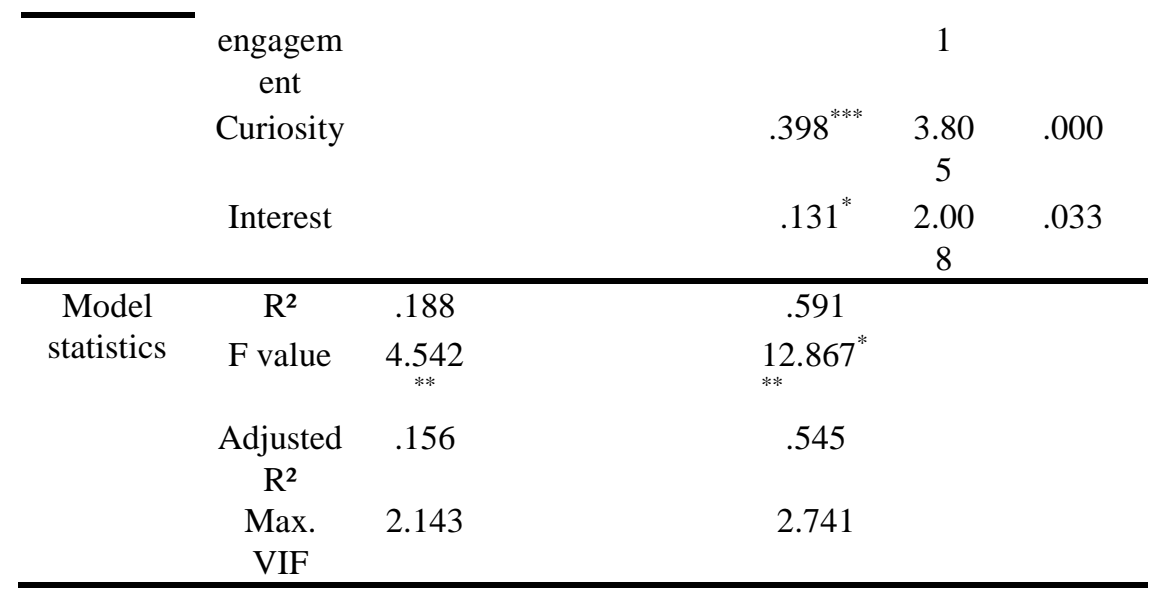

Note: $* * *$ means $\mathrm{p}<0.001, * *$ means $\mathrm{p}<0.01$ and $*$ means $\mathrm{p}<0.05$.

4.3.3 Regression analysis of knowledge sharing on individual innovation behavior As shown in Table 6, the standard regression coefficient of level of education and individual innovative behavior in Model 1 is 0.133 and significant at $\mathrm{P}<0.05$. In Model 2, knowledge sharing is added as an explanatory variable. The data in the table show that the standard regression coefficient of knowledge sharing and individual innovation behavior is significant $(\beta=0.674, \mathrm{p}=0.000)$, which supports the positive influence of knowledge sharing on individual innovation behavior, which means that $\mathrm{H} 3$ passes the empirical test.

Table 6 Regression analysis of knowledge sharing on individual innovation behavior of knowledge-based employees of the industrial new generation

\begin{tabular}{|c|c|c|c|c|c|c|c|}
\hline & \multirow[b]{2}{*}{$\begin{array}{c}\text { Variable } \\
\text { s }\end{array}$} & \multicolumn{3}{|c|}{ Model 1} & \multicolumn{2}{|c|}{ Model 2} & \multirow[b]{2}{*}{$\begin{array}{c}\text { sig } \\
\text { value }\end{array}$} \\
\hline & & Beta & $\begin{array}{c}\mathrm{t} \\
\text { value }\end{array}$ & $\begin{array}{c}\text { sig } \\
\text { value }\end{array}$ & Beta & $\begin{array}{c}\mathrm{t} \\
\text { value }\end{array}$ & \\
\hline \multirow{7}{*}{$\begin{array}{c}\text { Control } \\
\text { variables }\end{array}$} & Gender & -.069 & -.678 & .499 & -.128 & $\begin{array}{c}-1.65 \\
5\end{array}$ & .101 \\
\hline & Marriage & .038 & .351 & .726 & .074 & .887 & .377 \\
\hline & Age & -.170 & $\begin{array}{c}-1.09 \\
6\end{array}$ & .176 & .096 & .793 & .429 \\
\hline & Position & .068 & .667 & .667 & -.022 & -.281 & .779 \\
\hline & $\begin{array}{c}\text { Working } \\
\text { years }\end{array}$ & .086 & .598 & .551 & .101 & .913 & .363 \\
\hline & $\begin{array}{c}\text { Level of } \\
\text { educatio } \\
n\end{array}$ & $.133^{*}$ & 1.967 & .047 & .102 & $\begin{array}{c}1.03 \\
4\end{array}$ & .303 \\
\hline & $\begin{array}{c}\text { Nature } \\
\text { of } \\
\text { enterpris } \\
\mathrm{e}\end{array}$ & .113 & .895 & .373 & .084 & $\begin{array}{c}1.14 \\
7\end{array}$ & .254 \\
\hline $\begin{array}{c}\text { Independ } \\
\text { ent } \\
\text { variable }\end{array}$ & $\begin{array}{c}\text { Knowled } \\
\text { ge } \\
\text { sharing }\end{array}$ & & & & $.674^{* * * *}$ & $\begin{array}{c}9.91 \\
3\end{array}$ & .000 \\
\hline \multirow[t]{2}{*}{$\begin{array}{c}\text { Model } \\
\text { statistics }\end{array}$} & $\begin{array}{c}\mathrm{R}^{2} \\
\text { F value }\end{array}$ & $\begin{array}{c}.141 \\
3.680 \\
* *\end{array}$ & & & $\begin{array}{c}.455 \\
11.602^{*} \\
* * k\end{array}$ & & \\
\hline & $\begin{array}{c}\text { Adjusted } \\
\mathrm{R}^{2}\end{array}$ & .083 & & & .416 & & \\
\hline
\end{tabular}

ISSN: 0010-8189 


\subsubsection{Test on the mediating effect of knowledge sharing}

The results in table 7 are used to test the significant influence of intrinsic motivation on individual innovation behavior. Gender, marriage, age, position, working years, level of education and nature of enterprise are taken as control variables, intrinsic motivation is taken as independent variable, and individual innovation behavior is taken as a dependent variable (i.e. Model 1) for regression analysis, and the standard regression coefficient of intrinsic motivation and individual innovation behavior is significant $(\beta=0.810, p<0.001)$. In model 2 , gender, marriage and age are still the control variables, intrinsic motivation is the independent variable, and knowledge sharing is the dependent variable. The results show that intrinsic motivation has a significant impact on knowledge sharing, and the standard regression coefficient is 0.709 . On the basis of Model 1, knowledge sharing is added as an independent variable, and the standard regression coefficients are all significant $(\beta=0.164, p<0.05)$ and $(\beta=0.694$, $\mathrm{p}<0.001$ ), which shows that knowledge sharing has a partial mediating effect between intrinsic motivation and individual innovation behavior, and explains the mechanism between them of knowledge-based employees of the industrial new generation, that is, $\mathrm{H} 4$ passes the test.

Table 7 Test of mediating effect of knowledge sharing between intrinsic motivation and individual innovation behavior

\begin{tabular}{cccc}
\hline Variables & $\begin{array}{c}\text { Individual innovation } \\
\text { behavior }\end{array}$ & $\begin{array}{c}\text { Knowledge } \\
\text { sharing }\end{array}$ & $\begin{array}{c}\text { Individual innovation } \\
\text { behavior }\end{array}$ \\
\cline { 2 - 4 } & Model 1 & Model 2 & Model 3 \\
\hline Gender & -.126 & .038 & -.132 \\
Marriage & .088 & .058 & .155 \\
Age & .167 & .392 & .102 \\
Position & .051 & -.054 & .042 \\
Working years & -.107 & $.295^{* * *}$ & -.059 \\
Level of & $.164^{*}$ & $.297^{* *}$ & .039 \\
education & & -.045 & .007 \\
Nature of & .001 & $.709^{* * *}$ & $.694^{* * *}$ \\
enterprise & & & $.164^{*}$ \\
\hline Intrinsic & $.810^{* * *}$ & & .674 \\
motivation & & .564 & $25.225^{* * *}$ \\
Knowledge & & $17.918^{* * *}$ & .647 \\
sharing & & .532 & 2.582 \\
\hline $\mathrm{R}^{2}$ & .662 & 2.246 & \\
F value & $27.167^{* * *}$ & .638 &
\end{tabular}

Note: $* * *$ means $\mathrm{p}<0.001, * *$ means $\mathrm{p}<0.01$ and $*$ means $\mathrm{p}<0.05$.

Model 1 is to test whether each dimension of intrinsic motivation of knowledge-based employees of the industrial new generation can positively predict individual innovation behavior. The results in Table 8 show that each dimension of intrinsic motivation has a significant impact on individual innovation behavior. Model 2 is to test the effect of each dimension of intrinsic motivation of knowledge-based employees of the industrial new generation on knowledge sharing. The results show that the other four dimensions have significant influence except self-determination. Model 3 shows that when all dimensions of intrinsic motivation and knowledge sharing are 
simultaneously included in the regression model of individual innovation behavior, competency, work engagement, curiosity and interest remain significant, and it shows that the influence of competency, work engagement, curiosity and interest on individual innovation behavior is not completely influenced by knowledge sharing as an intermediate variable, thus $\mathrm{H} 4 \mathrm{~b}, \mathrm{H} 4 \mathrm{c}, \mathrm{H} 4 \mathrm{~d}$ and $\mathrm{H} 4 \mathrm{e}$ pass the test. In addition, self-determination is not significant for knowledge sharing, indicating that it has no mediating effect between self-determination and individual innovation behavior, that is, $\mathrm{H} 4 \mathrm{a}$ is not verified.

Table 8 Regression analysis of mediating effect between knowledge sharing in each dimension of intrinsic motivation and individual innovation behavior

\begin{tabular}{cccc}
\hline \multirow{2}{*}{ Variables } & $\begin{array}{c}\text { Individual innovation } \\
\text { behavior }\end{array}$ & Knowledge sharing & $\begin{array}{c}\text { Individual innovation } \\
\text { behavior }\end{array}$ \\
\cline { 2 - 4 } Gender & Model 1 & Model 2 & Model 3 \\
Marriage & -.123 & .033 & $-.128^{*}$ \\
Age & .020 & .073 & -.125 \\
Position & .093 & -.042 & .041 \\
Working years & .034 & .038 & .104 \\
Level of education & .069 & $.267^{* *}$ & .028 \\
Nature of enterprise & $.136^{*}$ & $.231^{*}$ & .015 \\
\hline Self-determination & .021 & .066 & -.011 \\
Competency & $.094^{*}$ & -.032 & .099 \\
Work engagement & $.279^{* *}$ & $.241^{*}$ & $.162^{*}$ \\
Curiosity & $.085^{*}$ & $.109^{*}$ & $.068^{*}$ \\
Interest & $.212^{*}$ & $.398^{* * *}$ & $.191^{*}$ \\
Knowledge sharing & $.318^{* * *}$ & $.131^{*}$ & $.298^{* * *}$ \\
\hline R & & & $.152^{*}$ \\
F value & .687 & .591 & .697 \\
Adjusted R & $19.614^{* * *}$ & $12.867^{* * *}$ & $18.755^{* * *}$ \\
Max. VIF & .652 & .545 & .660 \\
\hline
\end{tabular}

Note: $* * *$ means $\mathrm{p}<0.001, * *$ means $\mathrm{p}<0.01$ and $*$ means $\mathrm{p}<0.05$.

\section{Conclusions and Enlightenment}

\subsection{Research conclusions}

In this paper, based on the analysis of the pairwise correlation mechanism of intrinsic motivation, knowledge sharing and individual innovation behavior, the relationship among the variables is confirmed by empirical test with survey data, and it is found that: (1) The intrinsic motivation promotes the innovation behavior of the knowledge-based employees of the industrial new generation, that is, the stronger the intrinsic motivation, the greater the probability of the knowledge-based employees of the industrial new generation choosing innovation. However, different dimensions of intrinsic motivation have different effects on the innovation behavior of the knowledge-based employees of the industrial new generation. Among them, interests and hobbies play the most important role, followed by competency, curiosity, self-determination and work engagement. (2) The intrinsic motivation of industrial new generation knowledge -based employees can promote knowledge sharing. However, the dimensions of intrinsic motivation selected in this paper have significant differences in promoting knowledge sharing. Competency, work engagement, curiosity and interest can actively promote employees' knowledge sharing, among which curiosity has the greatest influence, followed by competency, and interest and work engagement have relatively low influence. However, the regression coefficient of self-determination and individual innovation

ISSN: 0010-8189 
behavior is not significant, which shows that employees with strong self-determination tend to think independently and solve problems, and often neglect to communicate with colleagues, so self-determination does not affect employees' knowledge sharing. (3) Knowledge sharing plays a partial mediating role between employees' intrinsic motivation and individual innovation behavior. After introducing the variable of knowledge sharing, the regression coefficient of intrinsic motivation to individual innovation behavior decreases significantly. According to the mediating effect test standard, the mediating effect of knowledge sharing is confirmed, in which the regression coefficient of competency, work engagement, curiosity and interest in intrinsic motivation to individual innovation behavior is significantly reduced, which indicates that knowledge sharing has partial mediating effect on the influence of competency, work engagement, curiosity and interest on individual innovation behavior. However, knowledge sharing has no mediating effect between self-determination and individual innovation behavior.

\subsection{Enlightenment for management}

Reasonable and effective incentives for the industrial new generation of knowledge workers to carry out innovation activities are an important means to enhance the innovation level of enterprises and maintain the core competitive advantage. However, in the existing research, there are still no effective measures to manage the individual innovation behavior of the knowledge-based employees of the industrial new generation, so the research conclusions of this paper can provide enlightenment for the innovation management of employees in small and medium-sized enterprises: (1) Enterprises should strengthen the intrinsic motivation of employees and highlight the key points of motivation by classification by means of strengthening the intrinsic motivation of the knowledge-based employees of the industrial new generation, especially the interest and competency, comprehensively considering the matching between the work itself and the individual characteristics of employees, timely understanding and meeting the relevant needs of their intrinsic motivation, and giving more work autonomy. (2) Enterprises should create an atmosphere of knowledge sharing and build a sharing platform and channel, by setting up knowledge sharing channels so that the knowledge-based employees of the industrial new generation will be given more opportunities to share and exchange knowledge, broaden their knowledge, and update and improve their knowledge in time, and encouraging the transformation of knowledge into innovative behavior and introducing corresponding incentive measures. (3) Enterprises should improve the innovation incentive system and respond to the innovation behavior in time. It is not enough to stimulate the knowledge-based employees of the industrial new generation and create a knowledge atmosphere, but to respond to the innovation behavior of them. According to the reinforcement theory, rewarding or affirming the encouraged behavior will increase the frequency of this behavior, so their innovation behavior should be reinforced in time.

\section{References}

[1] M. Gagne, R. Koestner, "Self-determination theory as a framework for Understanding Organizational Commitment," Paper Presented at the Annual Meeting of the Society for Industrial and Organizational Psychology, 2002.

[2] H.T. He, "Effectiveness of Knowledge Sharing: An Individual-Organization Oriented Perspective," Studies in Science of Science, vol. 03, 2011.

[3] L.F. Liao, "A Learning Organization Perspective on Knowledge-Sharing Behavior and Firm Innovation," Human Systems Management, vol. 25, no. 4, 2006.

[4] G.F. Yi, Y. Wang, "The influence mechanism of transformational leadership on the market performance of logistics enterprises-the double intermediary effect of management innovation and knowledge sharing," Financial Forum, vol. 01, pp. 94-103, 2021.

[5] J.Q. Yang, X.Y. Li, J. Bian, "Impact of Craftsman Spirit and Knowledge Sharing on Enterprise Innovation Performance," On Economic Problems, vol. 03, pp. 69-77, 2021.

[6] S.H. Liao,W.C. Fei, C.C. Chen, "Knowledge Sharing, Absorptive Capacity, and Innovation Capability : An Empirical Study of Taiwan's Knowledge-Intensive Industries,” Journal of Information Science, vol. 33, no. 6, 2007. 
[7] W.Q. Chen, "Culture of Organizational Innovation, Intensity of Organizational Culture and Innovative Behavior of Individual Employees: Hierarchical Linear Model Analysis," Psychological Science, vol. 6, 2013.

[8] H. Yang, C. Peng, R.X. Li, X.N. Yang, C.L. Lyu, "Transformational Leadership, Knowledge Sharing and R\&D Team Creativity: Inverse U-shaped Regulation of Heterogeneity of Team Members," Operations Research and Management Science, vol. 01, pp. 217-224, 2021.

[9] X. Liu, C.H. Zhao, Y.H. Tang, Impact of Craftsman Spirit and Knowledge Sharing on Innovation Performance of Enterprises," On Economic Problems, vol. 03, pp. 69-77, 2021.

[10] R.S. Woodworth, "Dynamic psychology," Journal of Genetic Psychology, vol. 33, no. 1, pp. 327-336, 1918.

[11] R.M. Ryan, E.L. Deci, "Self-determination theory and the facilitation of intrinsic motivation, social development, and well-being," American Psychologist, vol. 55, no. 1, pp. 68-78, 2000.

[12] W. Li, J.X. Mei, "Intrinsic Motivation and Employee Performance: Mediating Effect Based on Work Engagement," Management Review. vol. 8, 2013.

[13] T.M. Amabile, R. Conti, H. Coon, et al., "Assessing the work environment for creativity," Academy of Management Journal, vol. 39, no. 5, pp. 1154-1184, 1996.

[14] L. Lu, X.L. Liang, "Mediating Role of Knowledge Sharing in Interpersonal Interaction and Innovation ," Nankai Business Review, 2009.

[15] F.R. Kleysen, C.T. Street, "Toward a Multidimensional Measure of Individual Innovation behavior," Journal of Intellectual Capital, vol. 3, no. 2, 2001.

[16] V.G.S. Vander, J.S. Bunderson, "Learning and performance in multidisciplinary teams :The importance of collective team identification," Academy of Management Journal, vol. 48, no. 3, 2005.

[17] H.B. Vanden, J.D. Ridder, "The context of knowledge sharing," Paper presented at annual Conference of the ICA, Organizational Communication Division, San Diego, CA, 2003.

[18] J.Z. Yang, D.T. Yang, Q.J. Sun, "Mechanism of Organizational Culture Types on Employee Innovative Behavior," Science Research Management, vol. 9, 2012. 